\title{
Some effects of processing and storage on the nutritive value of milk and milk products
}

By B. A. Rolls and J. W. G. PorTer, National Institute for Research in Dairying, Shinfield, Reading $R G 2{ }_{9} A T$

Milk is an excellent food and its composition makes it an ideal medium for the growth of micro-organisms, including pathogens, which may be present in raw milk, either as a result of infections in the cow or pathogens introduced adventitiously during subsequent handling. To ensure a safe product of good keeping quality it is necessary to control microbial contamination. This is normally effected by some form of heat-treatment or by the conversion of liquid milk into a dry powder or a moist product, such as cheese or yoghurt, with its own built-in protection against spoilage. Such treatments may impair the nutritive value of milk by causing losses of the more labile constituents, and it is the purpose of this paper to outline recent work concerned with the nature and extent of the losses that occur during the heatprocessing and storage of liquid and dried milks, and during the preparation of some of the new products now being made from milk.

\section{Processing of liquid milk}

Pasteurization of milk, either by the holder process, in which milk is heated to $6 \mathrm{I}-65^{\circ}$ for $30 \mathrm{~min}$, or by the high-temperature short-time (HTST) process, in which it is heated to $7 \mathrm{I}-73^{\circ}$ for $15 \mathrm{~s}$, gives a product almost unchanged in flavour that will keep for several days if kept cool. For longer-term storage more vigorous sterilization is necessary. In-bottle sterilization, which involves heating bottled, homogenized milk to IIO-II $5^{\circ}$ for 20-40 min, imparts a marked cooked flavour due to browning. This older procedure is now rarely used: instead, ultra-high temperaturesterilized (UHT) milk is bottled and resterilized by heating at IIO-I I $2^{\circ}$ for $15^{-20}$ min, a procedure that imparts less of a cooked flavour. In the UHT process milk is sterilized by heating it to $130-15^{\circ}$ for I $\mathrm{s}$, either by the indirect process, in which the milk passes through a heat exchanger, or by the direct process, in which the milk is mixed with steam, the condensate being removed under reduced pressure (cf. Burton, I 969). UHT processing gives a safe product with less change of colour and flavour than does in-bottle or in-can sterilization; this is because at these high temperatures the rate of destruction of micro-organisms increases faster with increasing temperature than does the rate of browning. When filled aseptically into suitable containers such as Tetra Pak (London) Ltd (Richmond) cartons lined with aluminium foil, the milk can be kept for several months without refrigeration. 
The fat, fat-soluble vitamins, carbohydrates and minerals of milk are essentially unaffected by heat-treatment. Interest has therefore centred on the protein and water-soluble vitamin components.

Proteins in liquid milk. The proteins of raw milk are readily digested (true digestibility, 0.93 ) and of high biological value ( $\mathrm{BV}, 0.90$ ). Cow's milk contains slightly less of the sulphur amino acids than human milk or the FAO (1973) pattern, and the addition of methionine or cystine has been shown to improve its nutritive value in rat tests (Henry \& Kon, 1953). Conservative heat treatments, such as pasteurization and UHT processes, have little effect on the net protein utilization (NPU) of milk proteins, although the classic in-bottle sterilization procedure and the in-bottle resterilization of UHT milk cause losses in true digestibility, and a fall in BV due to reduced availability of lysine and methionine (Ford, Porter \& Burton, 1966).

Storage for several months at room temperature does not affect the nutritive value of the proteins of UHT or sterilized milk (Lembke, Frahm \& Wegener, 1968). Gelation of UHT or evaporated milks may occur at higher storage temperatures, but it is unlikely that the nutritive value of the protein would be affected.

It is well established that the whey proteins, particularly $\beta$-lactoglobulin, are denatured to some degree during heat-treatment of milk. The extent of denaturation is about $10 \%$ during pasteurization, $70 \%$ during UHT treatment and $75 \%$ during in-bottle sterilization. This denaturation does not affect the nutritive value of the whey proteins for the rat (Henry \& Porter, 1959) or for the human infant, and UHT milk has been used successfully in infant feeding (cf. Christen, I 967; Püschel, I968). However, calves given UHT milk, or spray-dried skim milk that had been submitted to a severe $\left(74^{\circ}\right.$ for $\left.30 \mathrm{~min}\right)$ preheating treatment and during which half or more of the whey proteins had been denatured, grew significantly less well than did calves given raw or pasteurized milk or spray-dried skim milk that had been given a mild ( $77^{\circ}$ for $15 \mathrm{~s}$ ) pre-treatment (cf. Roy, 1964). Recently, Braude, Newport \& Porter (197I) showed that the presence of a preponderance of denatured whey proteins caused similar, though less marked, effects on the growth of baby pigs. There is as yet no satisfactory explanation for this apparent dependence of the young calf and pig on a good supply of undenatured whey proteins, though it may be related to the effect of UHT treatment on the immune globulins or on the clotting of milk (Perkin, Henschel \& Burton, r973).

Water-soluble vitamins in liquid milk. Four vitamins of the B complex, riboflavin, nicotinic acid, pantothenic acid and biotin, are unaffected by heat treatment. The effects of the various heat treatments on the other, more labile, vitamins are summarized in Table I. Conventional pasteurization has little effect, the only significant change being a loss of $20-25 \%$ of the vitamin $\mathrm{C}$ due to the destruction of the dehydroascorbic acid formed by the action of dissolved oxygen on ascorbic acid. The old method of in-bottle sterilization caused considerable losses of vitamins; those of vitamin $B_{12}$ were a consequence of the oxidative destruction of ascorbic acid and could be alleviated by exclusion of oxygen, although the losses of thiamin and vitamin $B_{6}$ were not affected by the level of oxygen (Ford, 1957, 1967). The UHT process does not cause these extensive vitamin losses and, except for the 
Table I. Typical values for the proportion of heat-labile vitamins in raw milk lost during heat treatment

$\begin{array}{lccccc}\text { Type of milk } & \text { Thiamin } & \text { Vitamin } B_{6} & \text { Vitamin } B_{12} & \text { Folic acid } & \text { Vitamin C } \\ \begin{array}{l}\text { Pasteurized } \\ \text { In-bottle stetilized: }\end{array} & 0.10 & 0.10 & 0.10 & 0.10 & 0.25 \\ \quad \text { old method } & 0.35 & 0.50 & 0.90 & 0.50 & 0.90 \\ \quad \text { new method } & 0.20 & 0.20 & 0.20 & 0.30 & 0.60 \\ \text { Ultra-high-temperature } & & & & & \\ \quad \text { sterilized } & 0.10 & 0.10 & 0.10 & 0.10 & 0.25 \\ \text { Evaporated } & 0.20 & 0.40 & 0.80 & 0.25 & 0.60 \\ \text { Sweetened, condensed } & 0.10 & 0.10 & 0.30 & 0.25 & 0.25\end{array}$

destruction of dehydroascorbic acid, no more than about 10\% of any other vitamin is destroyed.

The conditions of storage are an important factor in the vitamin concentrations in milk. Milk, whether pasteurized, UHT-treated or sterilized, loses significant amounts of riboflavin, vitamin $C$ and vitamin $B_{6}$ if exposed to direct sunlight, diffuse daylight or fluorescent light. UHT milk is intended for long-term storage and is normally filled into containers that protect it from light and oxygen. The most important nutritive changes in UHT milk stored in Tetra Pak cartons are shown in Table 2. The losses of vitamin $\mathrm{C}$ and folic acid were markedly affected by

Table 2. Typical values for the proportion of vitamins lost from UHT-sterilized milk during storage in Tetra Pak cartons

\begin{tabular}{|c|c|c|c|}
\hline & $\begin{array}{l}\text { Initial oxygen } \\
\text { content }(\mathrm{mg} / \mathrm{kg})\end{array}$ & $\begin{array}{l}\text { Period of } \\
\text { storage }(d)\end{array}$ & $\begin{array}{l}\text { Loss during } \\
\text { storage }\end{array}$ \\
\hline \multirow[t]{2}{*}{ Vitamin $B_{6}$} & $0 \cdot I$ & & \\
\hline & $\begin{array}{c}I-2 \\
8\end{array}$ & 60 & 0.40 \\
\hline \multirow[t]{2}{*}{ Vitamin $B_{12}$} & 0.1 & & \\
\hline & $\begin{array}{c}I-2 \\
8\end{array}$ & 60 & $0.25-0.60$ \\
\hline \multirow[t]{3}{*}{ Vitamin $\mathrm{C}$} & 0.1 & 60 & 0.20 \\
\hline & $1-2$ & 14 & $\mathrm{I} \cdot \mathrm{O}$ \\
\hline & 8 & 7 & $\mathrm{x} \cdot \mathrm{O}$ \\
\hline \multirow[t]{3}{*}{ Folic acid } & 0.1 & 60 & 0 \\
\hline & $x-2$ & 60 & 0.05 \\
\hline & 8 & $\mathrm{r}_{4}$ & 1.00 \\
\hline
\end{tabular}

the residual oxygen level in the milk. When a process using evaporative cooling was used, and a milk very low in oxygen produced, there was little loss of vitamin $\mathrm{C}$ or folic acid during $180 \mathrm{~d}$ storage, but when the indirect UHT process was used without evaporative cooling, giving a product containing $8 \mathrm{mg}$ dissolved oxygen $/ \mathrm{kg}$, these vitamins were lost within a few days (Ford, Porter, 'Thompson, Toothill \& EdwardsWebb, I969; Burton, Ford, Perkin, Porter, Scott, Thompson, Toothill \& EdwardsWebb, 1970). From a nutritionist's viewpoint, therefore, the elimination of oxygen before storage is desirable, although this may result in a product with a more persistent 'cooked' flavour. 


\section{The removal of fission products from milk}

The treatment of milk to remove dangerous long-lived, bone-seeking isotopes such as ${ }^{137} \mathrm{Cs}$ and ${ }^{90} \mathrm{Sr}$ may be necessary following a nuclear accident. The removal of these isotopes may be effected by ion-exchange resins, but the procedure causes losses of some vitamins, particularly of thiamin, of which about two-thirds is lost, and these must be restored before use. The nutritional quality of milk treated by passage through a cation-exchange resin (Murthy, Campbell, Mazurovsky \& Edmondson, 1962) was found to be adversely affected in tests with baby pigs (Braude, Glascock, Newport \& Porter, I969), but subsequent elaboration of the procedure through the use of a mixed-bed column containing anionic- and cationicexchange resins gave a product that allowed normal growth in young pigs, rats and monkeys (Glascock \& Bryant, 1971; Cohen, Ashworth, Bryant \& Glascock, 1973).

\section{Concentrated milks}

Milks from which water has been removed and which have then been heatsterilized, such as evaporated and sweetened, condensed milks, are traditional and are still widely used. In the preparation of evaporated milk the liquid milk, after preheating, is concentrated by vacuum evaporation at $50-55^{\circ}$ and filled into cans which are then sterilized, typically at $115^{\circ}$ for $15 \mathrm{~min}$. In general, the nutrient losses in the traditional process are the same as for in-bottle sterilization (Table I). When evaporated milk is stored for several years progressive losses occur of vitamin $\mathrm{C}$, vitamin $\mathrm{B}_{6}$, vitamin $\mathrm{B}_{12}$ and possibly of ribollavin and folic acid. The biological value of the proteins varies little for up to a year at room temperature; losses of lysine then become apparent. Sweetened, condensed milk is prepared similarly, but since bacteriological safety is achieved by the addition of sucrose, less drastic heattreatment is necessary and the nutrient losses are only of the same order as those that occur during pasteurization.

More recently attention has turned to the use of methods of concentrating milk that do not involve the use of heat. Initially reverse osmosis and ultrafiltration were applied mainly to the treatment of whey, but increasing interest is now being shown in these procedures for concentrating whole milk. Glover (1971) concentrated milk to half its volume by both processes and reported good retention of fat and protein in the concentrate. With ultrafiltration, only the vitamins that are firmly proteinbound, such as vitamin $B_{12}$ and folic acid, are completely retained. With reverse osmosis, however, the only vitamin losses were less than $10 \%$ of the nicotinic acid and vitamin $B_{6}$. It should be stressed that these processes are concentrative and not preservative and that the resulting products need to be heat-treated if they are to be kept and sold in a liquid form.

\section{Cheese}

Cheese-making is one of the oldest, and quantitatively most important, methods of preserving the nutrients of milk. Cheeses may be made either from whole milk or from skim milk. 
Although the techniques of preparation of different whole-milk cheeses vary widely, their proximate compositions are broadly similar. The proteins of cheese, which are largely casein, are slightly inferior in quality to those of whole milk owing to the loss of the whey proteins with their higher content of the sulphur amino acids. Other losses in the partition between curd and whey include part of the calcium and significant proportions of the original nicotinic acid, vitamin $\mathrm{B}_{6}$, biotin, vitamin $B_{12}$, folic acid and vitamin $C$, and most of the lactose. Ripening destroys the residual vitamin $\mathrm{C}$ although-depending on the culture used-several of the $\mathrm{B}$ vitamins may be synthesized, mainly in the outer layers of the cheese (cf. Gregory, 1967).

Fat-soluble vitamins are retained in cheese made from whole milk but are not, of course, present in cheeses such as cottage cheese, made from skim milk.

\section{Other milk products}

Whey. The disposal or effective utilization of the large quantities of whey resulting from increased production of cheese has presented considerable problems during the last few years. Liquid whey, often preserved by the addition of formaldehyde, makes a useful and economical addition to the diet of fattening pigs and it is widely used for this purpose. Other substantial outlets for whey include its use for the preparation of lactose, and for the preparation of dried whey powder for use in foods and feeds. Even during the manufacture of spray-dried whey intended for human consumption, the Maillard reaction may proceed significantly, yielding many of the products observed in the casein-lactose system (see p. 14) and with concomitant loss of nutritive value (Ferretti \& Flanagan, 197I). Furthermore, the proteins of such powders are denatured and their functional properties, which make them valuable for inclusion in other processed foods, are largely lost. Recent developments in techniques of gel filtration and ultrafiltration have afforded methods of producing undenatured whey proteins for human foods. For instance, the use of a Calgon-Havens separator has given a concentrate containing 600-650 g protein $/ \mathrm{kg}$ with a $90 \%$ reduction in volume (McDonough, Mattingly \& Vestal, 1971).

Co-precipitates. The preparation of co-precipitates of casein and whey proteins, by acidifying heated milk, or mixtures of cheese whey and skim milk, provides an effective means of conserving milk proteins in a product that also contains all the calcium and phosphorus of the casein micelle. The good functional properties of coprecipitates make them an attractive raw material in the food industry, and the high nutritional value of their proteins was a factor in their choice for the milk biscuit (Muller, 1971), one of the most interesting new developments in dairy products. These biscuits have been found to be of high nutritive value (Townsend \& Buchanan, r967), to keep well and to be widely acceptable in several countries in south-east Asia.

\section{Dried milks}

Since micro-organisms cannot multiply in the absence of water, its removal from milk enables the product to be kept for long periods. Efficient spray- and rollerdrying of milks have little effect on their vitamin content or on the nutritive value 
of their proteins for rats, although less conservative roller-drying can result in some reduction in $\mathrm{BV}$. Loss of nutritive value may derive from protein-protein or proteincarbohydrate interactions, and results primarily from lowering of the availabilities of the sulphur amino acids and lysine, respectively, though protein-protein interactions may also cause the availability of all the amino acids to be reduced.

During the heat-treatment of milk, the protein may interact with lactose in the well-known Maillard-type reaction. The free $\in$-amino group of lysine combines with the aldehyde group of lactose and although the resulting lactulosyl-lysine is released on enzymic digestion, it is largely biologically unavailable to the animal and is excreted in the urine. It is, however, split by acid hydrolysis, so that conventional analysis reveals only a small loss in the total lysine content. Mauron, Finot and their co-workers (cf. Finot, 1973) have elucidated the chemical structure of this and other lysine-sugar compounds and have developed methods of determining them quantitatively in different products.

Provided that spray-drying has been efficient, the availability of lysine in the dried product will be high $(90-97 \%)$, whereas that in roller-dried milk can range from 60 to $95 \%$, according to the conditions. Actual destruction of significant amounts of lysine is confined to severely heated samples, when there may also be a loss of methionine availability of about $10 \%$. Animal tests have shown that, in general, spraydried milk has a higher Bv than roller-dried milk (Porter \& Garton, 1964). The older roller-drying processes may involve scorching and impart a marked cooked flavour; this is, however, desirable for the chocolate manufacturer.

If milk is to be used as a sole food, the losses in the limiting sulphur amino acids are of greater concern than the loss of lysine, for milk has such an abundance of lysine that a considerable proportion may be inactivated without a corresponding reduction in BV. Thus Bickel \& Mauron (r959) claimed that a severely heated rollerdried milk with only $50 \%$ of the lysine available proved satisfactory for infant feeding. On the other hand, in a mixed diet in which lysine is the limiting amino acid, such inactivation of lysine is the more serious factor. This has been illustrated recently by van den Bruel, Jenneskens \& $\mathrm{Mol}$ (1972), who tested the nutritive value for rats of spray-dried milks of almost unimpaired lysine availability and roller-dried milks of $86 \%$ and $64 \%$ lysine availability and found that only the last showed any lowering in NPU. However, when the milks were given in combination with gluten, so that lysine was limiting, the NPU of both roller-dried powders wete significantly lower than that of spray-dried milk.

Provided that storage conditions are satisfactory, dried whole- and skim-milk powders can be kept for several years with little loss of nutritive value of protein or vitamins. The main factors are storage time, temperature and relative humidity. At higher temperatures losses are more rapid, and whole-milk powder for tropical use should be packed under nitrogen or treated with antioxidants. Its moisture content should certainly be kept below $5 \%$, and the stored material should be protected from moisture. Unsatisfactory conditions can permit interactions similar to those induced by heat and the stored milk suffers a steady loss in nutritive value.

Roller- and spray-dried milks may be difficult to reconstitute owing to poor 
wettability. This problem is overcome in instant milks, which disperse readily and which are produced by re-moistening spray-dried skim-milk powders and redrying. Despite the double drying process the $\mathrm{BV}$ of the milk proteins should not be impaired.

\section{Conclusions}

The procedures at present used in milk processing are generally conservative and the losses of nutritive quality small. Future expansion of the existing market for milk and milk-based foods appears to depend to an increasing extent on the development of new products attractive to the consumer. Particular attention will probably be given to the development of concentrated products that reduce the need for packaging and transporting large volumes of water.

Milk and milk products make an important contribution to our daily needs for certain nutrients, particularly protein, calcium and some of the vitamins.

It is hoped that as much attention will be given in the future as has been given in the past to ensuring that processing procedures do not impair the unique properties of milk as a food.

\section{REFERENCES}

Bickel, H. \& Mauron, J. (1959). Annls paediat. I93, 55.

Braude, R., Glascock, R. F., Newport, M. J. \& Porter, J. W. G. (1969). F. Dairy Res. 36, r29.

Braude, R., Newport, M. J. \& Porter, J. W. G. (1971). Br. F. Nutr. 25, I13.

Burton, H. (1969). Dairy Sci. Abstr. 3r, 287.

Burton, H., Ford, J. E., Perkin, A. G., Porter, J. W. G., Scott, K. J., Thompson, S. Y., Toothill, J. \& Edwards-Webb, J. D. (1970). F. Dairy Res. 37, 529 .

Christen, J.-P. (1967). Revue méd. Suisse romande 87,78 .

Cohen, B., Ashworth, M., Bryant, D. T. W. \& Glascock, R. F. (1973). F. Dairy Res. 40, 53.

FAO (I973). (In the Press.)

Ferretti, A. \& Flanagan, V. P. (1971). F. Dairy Sci. 54, 1764.

Finot, P. A. (1973). In Proteins in Human Nutrition Ch. 34 [J. W. G. Porter and B. A. Rolls, editors]. London: Academic Press.

Ford, J. E. (1957). Э. Dairy Res. 24, 360.

Ford, J. E. (1967). F. Dairy Res. 34, 239.

Ford, J. E., Porter, J. W. G. \& Burton, H. (I966). Proc. int. Dairy Congr. xvi.. Munich B, p. 357.

Ford, J. E., Porter, J. W. G., Thompson, S. Y., Toothill, J. \& Edwards-Webb, J. (1969). F. Dairy Res. 36,447 .

Glascock, R. F. \& Bryant, D. T. W. (197I). F. Dairy Res, $3^{8}, 217$.

Glover, F. A. (1971). F. Dairy Res. 38, 373 .

Gregory, M. E. (1967). F. Dairy Res. 34, 169.

Henry, K. M. \& Kon, S. K. (1953). Br. F. Nutr. 7, 29.

Henry, K. M. \& Porter, J. W. G. (1959). Proc. int. Dairy Congr. xv. Lond. 1, 425.

Lembke, A., Frahm, H. \& Wegener, K. H. (1968). Kieler milchw. ForschBer. 20, 331.

McDonough, F. E., Mattingly, W. A. \& Vestal, J. H. (197r). F. Dairy Sci. 54, 1406.

Muller, L. L. (I97I), Dairy Sci. Abstr. 33, 659.

Murthy, G. K., Campbell, J. E. Jr, Mazurovsky, E. B. \& Edmondson, L. F. (I962). U.S. Pat. no. 3020161.

Perkin, A. G., Henschel, M. J. \& Burton, H. (1973). F. Dairy Res. 40, 215.

Porter, J. W. G. \& Garton, G. A. (1964). J. Dairy Res. 3r, zor.

Püschel, H. (1968). Tetra Pak 1968 (2), I8.

Roy, J. H. B. (1964). Vet. Rec. 76, 511 .

Townsend, F. R. \& Buchanan, R. A. (1967). Aust. F. Dairy Technol. 22, I39.

van den Bruel, A. M. R., Jenneskens, P. J. \& Mol, J. J. (1972). Ned. Melk-en Zuiveltijdschr. 26, I9. 